\title{
Risky sexual behavior and knowledge of STIs/ AIDS among university health students
}

\author{
Comportamento sexual de risco e conhecimento sobre IST/SIDA em universitários da saúde \\ Comportamientos sexuales de riesgo y conocimiento sobre las ITS/SIDA \\ en los universitarios de la salud
Willian Barbosa Sales*; Cristiano CaveiãO**; Angelita Visentin ${ }^{* * *}$; Daniela Mocelin****; Priscila Moreira da

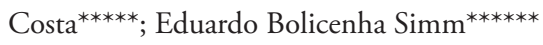

\begin{abstract}
Background: Risky sexual behaviors are associated with the number of sexual partners, and non-use of condom, among other factors. Objective: To identify the profile of health students attending a higher education institution, according to demographic and sexual characteristics.

Methods: This is a prospective, cross-sectional and descriptive study with a quantitative approach using a sample of 819 university health students. We used a questionnaire in order to obtain information on the students' demographic characteristics, sexual behaviors and knowledge of STIs/AIDS. We defined risky behavior as the adoption of 2 or more of the following sexual behaviors: non-use of condom, more than 10 sexual partners, sexual intercourse under the influence of alcohol/drugs, and sexual intercourse with little or recently known person.

Results: The sample was composed of $77.41 \%$ (634) of women and 22.59\% (185) of men, with a mean age of 24.4 years (SD \pm 6.7 ). Most participants (52\%) reported risky behaviors and insufficient knowledge of STIs.

Conclusion: The fact that $52 \%$ of the participants reported risky sexual behaviors points to the need for preventive interventions among this population, aimed at raising awareness and reducing the risk of STIs.
\end{abstract}

Keywords: sexually transmitted infections; acquired immunodeficiency syndrome; students, health occupations; sexual behavior

\section{Resumo}

Enquadramento: O comportamento sexual de risco esta relacionado com o número de parceiros sexuais, não utilização de preservativos, entre outros fatores.

Objetivo: Caracterizar o perfil dos universitários da área de saúde numa intituição de ensino superior (IES), quanto a aspetos demográficos e sexuais. Metodologia: Estudo descritivo, prospetivo e transversal com abordagem quantitativa, realizado com 819 universitários da área da saúde. Utilizouse um questionário com questões sobre aspetos demográficos, conduta sexual e conhecimento sobre IST/SIDA. Adotou-se como comportamento de risco 2 ou mais comportamentos sexuais: não utilização de preservativos, mais de 10 parceiros sexuais, manter relações sob efeito de álcool/drogas e com pessoa pouco ou recentemente conhecida. Resultados: Setenta e sete vírgula quarenta e um por cento (634) são mulheres e 22,59\% (185) homens; com média de idade de 24,4 anos (DP $\pm 6,7), 52 \%$ apresentaram comportamento de risco e conhecimento insuficiente sobre IST.

Conclusão: Dos participantes, $52 \%$ possuem comportamento de risco sexual, facto que exige desenvolvimento de trabalhos preventivos com esta população, através de atividades educativas, visando consciencialização e diminuição dos riscos para IST.

Palavras-chave: infecções sexualmente transmissíveis; síndrome de imunodeficiência adquirida; estudantes de ciências da saúde; comportamento sexual

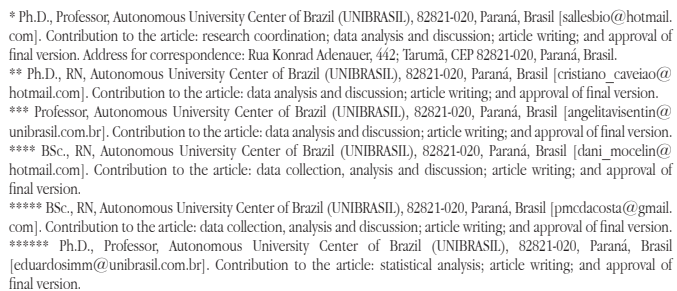

Ph.D., Professor, Autonomous University Center of Brazil (UNIBRASLL), 82821-020, Paraná, Brasil lsallesbio@ hotmail final version. Address for correspondence: Rua Konrad Adenauer, 442; Tarumã, CEP 82821-020, Paraná, Brasil. ** Ph.D., RN, Autonomous University Center of Brazil (UNIBRASIL), 82821-020, Paraná, Brasil (cristiano caveiao( *** Professor, Autonomous University Center of Brazil (UNIBRASIL), 82821-020, Paraná, Brasil langelitavisentin unibrasil.com. br]. Contribution to the article: data analysis and discussion; article writing; and approval of final version

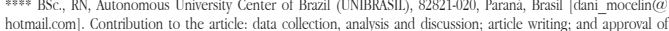
final version.

作

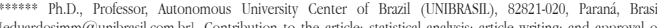
final version.

\section{Resumen}

Marco contextual: La conducta sexual de riesgo se relaciona con el número de parejas sexuales, no usar preservativo y otros factores.

Objetivo: Caracterizar el perfil de los universitarios del área de la salud en una IES en cuanto a los aspectos demográficos y sexuales.

Metodología: Estudio descriptivo, prospectivo y transversal con un enfoque cuantitativo realizado con 819 estudiantes universitarios del área de la salud. Se utilizó un cuestionario con preguntas sobre aspectos demográficos, conducta sexual y conocimiento sobre las ITS/sida. Se adoptaron como conducta de riesgo dos o más comportamientos sexuales de los siguientes: no usar preservativo, más de diez parejas sexuales, mantener relaciones bajo la influencia de alcohol/ drogas y con personas que se conocen poco o hace poco. Resultados: El 77,41 \% (634) son mujeres y el 22,59 \% (185) hombres con una edad media de 24,4 años $(D E \pm 6,7)$, el $52 \%$ tenía un comportamiento de riesgo y un conocimiento insuficiente sobre las ITS.

Conclusión: El $52 \%$ de los participantes tiene comportamientos sexuales de riesgo, un hecho que requiere que se desarrolle una labor preventiva con esta población a través de actividades educativas dirigidas a concienciar y reducir los riesgos de ITS.

Palabras clave: infeciones de transmisión sexual; síndrome de inmunodeficiencia adquirida; estudiantes del área de la salud; conducta sexual

Received for publication: 17.03 .16

Accepted for publication: 22.07.16 


\section{Introduction}

The acquired immunodeficiency syndrome (AIDS), identified in the 1980s, is a major health issue. Young adult population is the most vulnerable and diseaseaffected age group. The prevalence of AIDS and other sexually transmitted infections (STIs) is increasing, and risky sexual behaviors continue to be the main route of human immunodeficiency virus (HIV) transmission (Duarte, Parada, \& Souza, 2014, Rocha \& Silva, 2014; Flora, Rodrigues, \& Paiva, 2013).

The epidemiological profile of AIDS has changed over the years. Sexual transmission (for example, among men who have homosexual intercourse and sex workers), blood transmission (through transfusion of blood and blood products), and use of injectable drugs were the main routes of transmission. Heterosexual intercourse has now surpassed homosexual intercourse as the main route of transmission, and the number of women infected by the virus has increased significantly (Duarte et al., 2014; Rocha et al., 2014). The absolute difference in the number of heterosexual and homosexual individuals explains the higher incidence of the disease among heterosexual individuals.

Between January and June 2014, the Brazilian Notifiable Diseases Information System (Sistema de Informação de Agravos de Notificação, SINAN NET) registered 70677 cases of HIV infection among the adult population. The Department of STI, AIDS and Viral Hepatitis estimated that there were approximately 734000 people living with AIDS in Brazil in 2014, which corresponded to a $0.4 \%$ prevalence rate (Ministério da Saúde, Secretaria de Vigilância em Saúde - Departamento de DST, Aids e Hepatites Virais, 2013). This estimate included the young adult population.

Many factors contribute to risky behaviors among young adults. One of them is the behavioral changes that they experience when entering university, namely increased responsibilities, financial autonomy, power to make their own choices and decisions, increased contact with alcohol and drugs and more opportunities to use them, and unsafe sex. Consequently, they become more vulnerable to STIs/ AIDS, since vulnerability involves individual, social and programmatic components (Campo-Arias, Ceballo, \& Herazo, 2010; Santos \& Oliveira, 2009).
Given the behavioral changes experienced by university students, it is of high importance to analyze their sexual behaviors and knowledge of STIs. This is an important factor for the development of preventive interventions among young people, and, for this reason, there is a need to raise the awareness of the academic population to the fact that anyone can acquire STIS/AIDS. Therefore, we defined the following research objective: To identify the profile of health students attending a Higher Education Institution (HEI) based on their demographic and sexual characteristics.

\section{Background}

Risky behaviors are related to: number of sexual partners, non-use of condom and/or contraceptive methods; sexual intercourse under the influence of alcohol and/or drugs; and sexual intercourse with little or recently known person. These behaviors are associated with family and cultural variables, which influence the personality traits that are being developed (Campo-Arias et al., 2010; Falcão et al., 2007; Mehra, Kyagada, Ostergren, \& Agardh, 2014; Santos \& Oliveira, 2009).

The individual component relates to individuals' knowledge on the issue, their ability to incorporate it in their daily concerns, beliefs, desires, religion, and the real possibility of transforming these concerns into actual practice. The social component refers to cultural factors, work relationships, management relationships, intergenerational relationships, gender issues, access to goods, and means for obtaining information. Finally, the programmatic component relates to the access to public policies on health and education, allowing for the protection and management of STIs and HIV/AIDS (Campo-Arias et al., 2010; Barbosa, Garcia, Manzato, Martins, \& Vieira 2006; Santos \& Oliveira, 2009).

STIs are mainly transmitted through unsafe sexual contact with an infected person, and sharing injectable drug syringes and needles. The main STIs are AIDS, chancroid, chlamydia, gonorrhea, condyloma (HPV - human papilloma virus), pelvic inflammatory disease (PID), donovanosis, viral hepatitis, herpes, human T-lymphotropic virus (HTLV) infection, lymphogranuloma venereum, 
syphilis, and trichomoniasis (Martins et al., 2006). Every year, an estimated four million young people become sexually active and, as such, vulnerable to STIs. Approximately 12 million new cases of STIs are reported every year among young people under the age of 25 years (Barbosa et al., 2006; Sousa, Sousa, Lopes, \& Rodrigues, 2011).

\section{Research Question}

What is the association between risky behavior patterns and the level of knowledge on STIs/AIDS among university health students?

\section{Methodology}

This prospective, cross-sectional and descriptive study with a quantitative approach was conducted among students attending programs in the areas of nursing, biomedicine, physical education, pharmacy, nutrition, physical therapy, and psychology in a private HEI in Brazil. The study population was composed of 995 university students who were enrolled in 2015. We administered the questionnaire to 946 health students, and excluded 127 questionnaires: 62 respondents were not sexually active, and 65 questionnaires were inconsistently completed. The sample was composed of 819 university students.

For data collection, participants completed a questionnaire, which was adapted from the survey on the knowledge, attitudes and practices of the Brazilian population of the Ministry of Health, Health Surveillance Secretary - Department of STI, AIDS and Viral Hepatitis (MS, 2011), and the youth risk behavior survey conducted in 2010 (Campo-Arias et al., 2010). The questionnaire consisted of 31 questions on demographic and health-related aspects, sexual practices and knowledge of STIs/AIDS. Since it was already validated by the authors, the questionnaire was not submitted to a validation process by the researchers.

Data were collected between classes, in classrooms, from June to September 2015, after the university students who accepted to participate had signed an informed consent form. Participants took approximately 10 minutes to complete the questionnaire.
The study sample included university health students (in the areas of nursing, medicine, physical education, pharmacy, nutrition, physical therapy, and psychology) who were enrolled in 2015, reported being sexually active, and completed the questionnaire in full. University students who reported not being sexually active, did not complete the questionnaire in full, and did not sign the informed consent form for participation in the study were excluded from the sample.

Based on the risk criteria established by Campo-Arias et al. (2010), we defined risky behavior as referring to two or more of the following five sexual risky behaviors throughout life: inconsistent use of condoms; more than 10 sexual partners; sexual intercourse after alcohol consumption; sexual intercourse after the consumption of any illegal substance; and sexual intercourse with little or recently known sexual partners.

Data were entered and processed using the Statistical Package for Social Sciences (SPSS) software, version 22.0. We used statistical and descriptive data analysis, as well as variable cross-analysis in order to find associations between variables. We estimated the frequency, mean and standard deviation to identify the association between sexual behavior and level of knowledge of STIs/AIDS. We used $p<.05$ to assess the significance between results and the Chi-square test given its adequacy for quantitative data analysis.

The study was approved by the Research Ethics Committee of the Autonomous University Center of Brazil (opinion 44365115.9.0000.0095). We complied with the ethical principles of Resolution 466/12 on research projects involving human beings.

\section{Results}

The sample consisted of 819 students, of whom $77.41 \%$ (634) were women; mean age of 24.4 years ( $S D$ \pm 6.7 ). In relation to sexual orientation, $97.1 \%$ (795) reported being heterosexual, 1.8\% (15) bisexual, and 1.1\% (9) homosexual. Most respondents (67.8\%; 555) had a family income of 1 to 4 minimum wages, 25.9\% (212) had a family income of 5 to 9 minimum wages, and $6.3 \%$ (52) had an income above 10 minimum wages.

Table 1 shows the number of participants by gender, mean age, and onset of sexual activity per program. 
Table 1

Demographic aspects of university students per program

\begin{tabular}{lccccc}
\hline Program & Women & Men & Mean age & Onset of sexual activity (years) & Total number of participants \\
\hline Biomedicine & 112 & 13 & 22.47 & 16.8 & $125(15.26 \%)$ \\
Nursing & 100 & 10 & 28.81 & 16.3 & $110(13.43 \%)$ \\
Pharmacy & 66 & 19 & 25.37 & 16.7 & $85(10.37 \%)$ \\
Physical Therapy & 90 & 18 & 23.3 & 16.8 & $108(13.18 \%)$ \\
Nutrition & 89 & 12 & 23.5 & 16.4 & $101(12.33 \%)$ \\
Physical Education & 71 & 79 & 24.28 & 16.6 & $150(18.31 \%)$ \\
Psychology & 106 & 34 & 24.12 & 16.6 & $140(17.09 \%)$ \\
Total & 634 & 185 & 24.36 & 16.66 & $819(100 \%)$ \\
\hline
\end{tabular}

Participants were asked about their lifestyles. With regard to smoking, $91.8 \%$ (752) reported not smoking, 8.2\% (67) reported smoking, 72.8\% (596) reported never having smoked, and 27.2\% (223) reported having smoked at some point in their life. With regard to alcohol consumption, 50.2\% (411) reported drinking alcohol. With regard to drug use, 7\% (57) used drugs and 93\% (762) did not use drugs, and, of these, 23.2\% (190) have used illicit drugs. When asked about congenital disorders, $2 \%$ (16) had a congenital disorder; 62.1\% (509) had regular medical check-ups, and 310 did not have regular medical check-ups. With regard to continuous medication, $81.80 \%$ (670) did not use medication.

Table 2 shows the contraceptive or prevention methods used by the participants.

Table 2

Distribution of the most common contraceptive or prevention methods among university students

\begin{tabular}{lcc}
\hline Contraceptive method & $N$ & $\%$ \\
\hline Pill & 379 & 46.27 \\
Male condom & 280 & 34.18 \\
Do not use & 164 & 20.02 \\
Contraceptive injection & 32 & 3.90 \\
Female condom & 25 & 3.05 \\
Intrauterine device & 17 & 2.07 \\
Coitus interruptus & 10 & 1.22 \\
Ovulation calculator & 7 & 0.85 \\
Tubal ligation & 7 & 0.85 \\
Morning-after pill & 7 & 0.85 \\
Vasectomy & 3 & 0.36 \\
Cervical mucus (mucus thickening during the fertile period) & 2 & 0.24 \\
Diaphragm & 0 & 0 \\
\hline
\end{tabular}

AIDS was the most commonly known disease among STIs known to the students. university students: $98.16 \%$ (804). Table 3 shows the 
Table 3

Students' knowledge of sexually transmitted infections

\begin{tabular}{lcc}
\hline Sexually transmitted infections (STIs) & $N$ & $\%$ \\
\hline Acquired Immunodeficiency Syndrome (AIDS) & 804 & 98.16 \\
Syphilis & 712 & 86.93 \\
Herpes & 678 & 82.78 \\
Human papilloma virus (HPV) & 670 & 81.80 \\
Gonorrhea & 637 & 77.77 \\
Hepatitis & 562 & 68.62 \\
Chlamydia & 399 & 48.71 \\
Chanchroid & 340 & 41.51 \\
Trichomoniasis & 284 & 34.67 \\
Pelvic inflammatory disease (PID) & 217 & 26.49 \\
Lymphogranuloma venereum & 167 & 20.39 \\
Human T-lymphotropic virus (HTLV) & 166 & 20.26 \\
Donovanosis & 69 & 8.42 \\
\hline
\end{tabular}

Table 4 shows the percentage of students with risky behaviors per program.

Table 4

Percentage of students with risky behaviors per program

\begin{tabular}{lcc}
\hline Program & $N$ & $\%$ \\
\hline Biomedicine & 68 & 54.4 \\
Physical Education & 77 & 51.3 \\
Nursing & 60 & 54.5 \\
Pharmacy & 51 & 60 \\
Physical Therapy & 55 & 50.9 \\
Nutrition & 56 & 55.4 \\
Psychology & 65 & 46.4 \\
\hline
\end{tabular}

Table 5 shows the percentage of answers about Chi-square test for group comparison. University knowledge of STIs by risk group and result of the students were asked about their knowledge of STIs.

Table 5

Percentage of answers about knowledge of STIs according to risk group and result of the Chi-square test for group comparison

\begin{tabular}{lccc}
\hline STI & Group with risky behaviors & Group without risky behaviors & $\rho$-value \\
\hline AIDS & $98 \%$ & $98 \%$ & .915 \\
HPV & $82 \%$ & $82 \%$ & .859 \\
Chancroid & $40 \%$ & $43 \%$ & .488 \\
Chlamydia & $52 \%$ & $46 \%$ & .122 \\
Gonorrhea & $76 \%$ & $79 \%$ & .328 \\
PID & $26 \%$ & $27 \%$ & .714 \\
Donovanosis & $9 \%$ & $8 \%$ & .505 \\
Hepatitis & $72 \%$ & $66 \%$ & .085 \\
Herpes & $82 \%$ & $83 \%$ & .733 \\
HTLV & $20 \%$ & $21 \%$ & .725 \\
Lymphogranuloma & $20 \%$ & $21 \%$ & .858 \\
Syphilis & $87 \%$ & $87 \%$ & .996 \\
Trichomoniasis & $33 \%$ & $37 \%$ & .289 \\
\hline
\end{tabular}


Table 5 shows the cross-analysis of data on risky behaviors and knowledge about each STI. We used the $p$-value $(<.05)$ to assess any significant differences between the knowledge of STIs and risky behaviors. No significant difference was found between the groups with risky behavior and the groups without risky behavior concerning the knowledge of STIs.

The use of condoms among university students in every sexual activity was $19.29 \%$ (158) in women and 3.90\% (32) in men. When asked about the use of condoms in the last sexual intercourse, $14.40 \%$ (118) of women had used a condom, and 3.41\% (28) of women reported using it as contraceptive method. With regard to those who had developed STIs, 2.07\% (17) were women, of whom 100\% (17) had received treatment. With regard to taking serological tests in routine consultations, the same percentage of participants had taken serological tests and rapid tests for HIV and hepatitis/NDRL: 62\% (508).

\section{Discussion}

It was possible to characterize the profile of university students in university health programs concerning demographic and sexual aspects, and the association between risky behaviors and knowledge of STIs. Most participants in this study were women, with a mean age of 24.4 years, who had healthy lifestyles, and who reported having 1 to 3 sexual partners, having started their sexual activity with a mean age of 16.66 years, and using condoms and the pill as main contraceptive method. Only women reported having had some STI. In their study, Moghaddam, Mashadi, Fathimoghadam, and Pourafzali (2015) surveyed 590 higher education students in Iran, of whom $71.4 \%$ were women; this is consistent the study by Barbosa et al. (2006), with 888 higher education students, of whom 650 (75.3\%) were women. These data are similar to this study, which showed a percentage of $77.41 \%$ of women in healthrelated programs, and a predominance of women in higher education. Our study is not in line with Campo-Arias et al. (2010), who found a predominance of men (78.2\%). However, only middle-school students were interviewed. These data show the reality of the country in relation to higher education. According to the 2013 census of the Brazilian Institute for Geography and Statistics (Instituto Brasileiro de Geografia e Estatística, IBGE), 55.5\% of students enrolled in HEIs are women, and 59.2\% of graduating students are women, which is in line with this study. The mean age of the participants in this study was 24.36 years, as in the study of Barbosa, in which participants had a mean age of 24.2 years (Barbosa el al., 2006). In other studies on this topic, the participants' mean age was 20.8 years (Moghaddam et al., 2015) and 14.8 years (Campo-Arias et al., 2010). In relation to sexual orientation, there is a predominance of heterosexual individuals in this study (97.06\%), which is in line with the percentage of $95.9 \%$ described in another study (Barbosa et al., 2006). Data on homosexual and bisexual individuals are divergent in another study, in which $2.4 \%$ are homosexual and $1.7 \%$ are bisexual (Barbosa et al., 2006). This shows an increase in the bisexual orientation in relation to homosexuality in this study: $1.83 \%$ of bisexual individuals and $1.09 \%$ of homosexual individuals.

In this study, 35\% of the students (21 men and 7 women) reported having had same-sex experiences (Moghaddam et al., 2015). In relation to the age of onset of sexual activity, these results are similar to the study of Sant' Anna, Carvalho, Passarelli, and Coates (2008), in which the mean age of onset was 17 years. The most often reported contraceptive methods in these studies were male condoms and the pill (Oliveira, Oliveira, Pita, \& Cardoso, 2009; Barbosa et al., 2006) which match the methods reported in this study: $34.18 \%$ and 46.27 , respectively. In another study, the results are similar: $27 \%$ of participants reported the condom and 22.5\% reported the pill (Silva, Camargo, \& Iwamoto, 2014). Another method reported by many students was the coitus interruptus (Barbosa et al., 2006). In this study, this method, which is a risky behavior for STIs and unwanted pregnancy, was reported by $1.22 \%$ of participants.

In relation to the onset of sexual activity, Barbosa et al. (2006) found a mean age of 17 years, Moghaddam et al. (2015) found a mean age of 18 years, Gubert et al. (2013) found a mean age of 16.7 years, and in this study we found a mean age of onset of 16.6 years, which is in line with data described in the literature on higher education students. Undergraduate nursing students reported starting their sexual activity before students in other programs. Biomedicine and physical therapy students reported starting their sexual activity later than other students. So far, no studies have been published on the association between age at first sexual intercourse and undergraduate programs. 
With regard to lifestyles, students were asked about smoking habits, and use of alcohol and illicit drugs. In this study, $41 \%$ of participants have smoked, $92.3 \%$ have drunk alcoholic beverages, and 8\% have used illicit drugs (Campo-Arias et al., 2010). In this study, only the percentage of drug use is higher: $23.2 \%$ of the respondents.

More than $90 \%$ of the sampled students in another study reported knowledge of AIDS, gonorrhea, herpes, hepatitis and syphilis (Barbosa et al., 2006), although this percentage is considered to be low for university health students. Students have little knowledge about HIV/AIDS, being more vulnerable to the disease and to imagining it as something that will never happen to them (Souza, 2007).

Many authors have discussed the key aspect of using condoms for the prevention of STIs: condom use is inconsistent, with only $33.7 \%$ of the students using it (Campo-Arias et al., 2010); 33.4\% did not use condoms in their last sexual intercourse, and women use condoms more often than men $(72.2 \%$ of respondents) and $50 \%$ of the total respondents did not use it in every sexual intercourse (Oliveira et al., 2015). It should also be noted that young people aged between 14 and 19 years did not use a condom in every sexual intercourse: $73.9 \%$ of men and $67.1 \%$ of women (Rocha \& Silva, 2014; Oliveira et al., 2009). Although students have adequate knowledge of STIs, they did not use condoms in every sexual intercourse, which shows that holding knowledge is not a guarantee of a risk-free sexual activity (Rocha \& Silva, 2014). Based on the findings of this study, students have risky behaviors because they do not use a condom in all sexual relations.

In this study, women report a greater use of condoms than men, both in all and in the last sexual intercourse, which contradicts the study of Mehra et al. (2014), in which women have a higher prevalence (50\%) of inconsistent use of condoms than men (37\%; Falcão Júnior et al., 2007). There is also evidence of symmetry between men and women regarding the inconsistent use of condoms (Souza et al., 2011).

In this study, more than half of university students (52\%) engaged in risky sexual behaviors. We had assumed that this percentage would be lower since this was a study with health students. The results concerning the association between risky behaviors and knowledge of STIs show that, despite being familiar with the diseases to which they are vulnerable, students take no preventive actions. One of the risk factors is the consumption of alcohol and/or drugs before sexual intercourse since it increases sexual libido but affects reasoning ability. The percentage of students who had used alcohol or other drugs before sexual relations was higher than in other studies: $73.9 \%$ of men and $67.1 \%$ of women (Rocha \& Silva, 2014); $18.4 \%$ of young people reported having sexual intercourse after drinking alcohol, and 5.8\% after using illicit drugs (Campo-Arias et al., 2010). The percentage of alcohol consumption before sexual intercourse was of 16\% among men and 9\% among women (Moghaddam et al., 2015). Another risk factor is having sexual relations with people they did not know or had only recently met. Our results are in line with the study of Campo-Arias et al. (2010), where $40 \%$ of the sampled participants had sexual relations with a person they did not know well. In another study (Oliveira et al., 2015), this percentage was lower $(5.2 \%)$.

In this study, students had between 1 and 15 sexual partners since the onset of sexual activity (Dessunti \& Reis, 2012). The existence of multiple sexual partners is also a risk factor for STIs. The percentages reach approximately $40 \%$ of young people (Mehra et al., 2014; Moghaddam et al., 2015). In this study, 8\% of participants reported having between eight and 10 sexual partners.

We considered the possibility of biased results, because participants may have lied or omitted relevant information for being a sensitive topic. However, this does not invalidate the study. A limitation of this study may be the fact that, as in other studies, we did not question the participants about their marital status.

\section{Conclusion}

This study was important to identify the profile of university health students regarding risky sexual behaviors. We found that a high percentage (52\%) of university students engage in risky behaviors. We found no significant difference in the association between the groups with and without risky behaviors and the knowledge of STIs, which confirms that holding knowledge about STIs (risky practices) is not enough to reduce STIs. As in other studies, a relevant fact was the inconsistent use of condoms, which requires the development of preventive 
interventions among this population, through educational activities, aimed at raising awareness and reducing risk for STIs. University students have shown to have a good knowledge of HIV/AIDS, syphilis, HPV, and herpes. Their level of knowledge of other STIs was insufficient. They also do not use condoms as a contraceptive method, thus being more vulnerable to these infections.

Further studies should be conducted to raise awareness, prevent and educate the university population, since prevention is the most effective strategy against these infections. Therefore, health education plays a key role, and universities, due to their high number of young students who are sexually active, become the main target for an intervention program, aimed at minimizing the risks of STIs. Therefore, this study cannot be generalized and only concerns the sample under analysis.

\section{References}

Barbosa, R. G., Garcia, F. C., Manzato, A. J., Martins, R. A., \& Vieira, F. T. (2006). Conhecimento sobre DST/AIDS, hepatites e conduta sexual de universitários de São José do Rio Preto, SP. Jornal Brasileiro de Doenças Sexualmente Transmissiveis, 18(4), 224-230. Retrieved from http://www.dst.uff.br// revista18-4-2006/CAP1ConhecimentoSobreDSTAIDS.pdf

Campo-Arias, A., Ceballo, G. A., \& Herazo E. (2010). Prevalence of pattern of risky behaviors for reproductive and sexual health among middle - and high-school students. Revista LatinoAmericana de Enfermagem, 18(2), 170-174. doi: 10.1590/ S0104-11692010000200005

Dessunti, E. M., \& Reis, A. O. (2012). Vulnerabilidade às DST/ AIDS entre estudantes da saúde: Estudo comparativo entre primeira e última série. Ciência Cuidado e Saúde, 11(Supl.), 274-283. doi: 10.4025/cienccuidsaude.v11i5.17738

Duarte, M. T., Parada, C. M., \& Souza, L. R. (2014). Vulnerability of women living with HIV/Aids. Revista Latino-Americana de Enfermagem, 22(1), 68-75. doi: 10.1590/0104-1169.2837.2377

Falcão Júnior, J. E., Lopes, E. M., Freitas, L. V., Pinheiro, S., \& Ximenes, L. B. (2007). Perfil e práticas sexuais de universitários da área de saúde. Escola Anna Nery Revista de Enfermagem, 11(1), 58-65. doi: 10.1590/\$1414-81452007000100008

Flora, M. C., Rodrigues, R. F., \& Paiva, H. M. (2013). Intervenções de educação sexual em adolescentes: Uma revisão sistemática da literatura. Revista de Enfermagem Referência, 3(10), 125134. doi: $10.12707 /$ RIII1229
Gubert, F. A., Vieira, N. F., Pinheiro, P. N., Oriá, M. O., Almeida, P. C., \& Araújo, T. S. (2013). Translation and validation of the Parent-adolescent Communication Scale: Technology for DST/HIV prevention. Revista Latino-Americana de Enfermagem, 21(4), 851-859. doi: 10.1590/S010411692013000400004

Martins, L. B., Costa-Paiva, L. H., Osis, M. J., Sousa, M. H., PintoNeto, A. M., \& Tadini, V. (2006). Fatores associados ao uso de preservativo masculino e ao conhecimento sobre DST/AIDS em adolescentes de escolas públicas e privadas do Município de São Paulo, Brasil. Cadernos de Saúde Pública, 22(2), 315323. doi: 10.1590/S0102-311X2006000200009

Mehra, D., Kyagada, E., Ostergren, P. O., \& Agardh, A. (2014). Association between self-reported academic performance and risky sexual behavior among Ugandan University Students: A cross sectional study. Global Journal Health Science, 6(4), 183-195. doi: 10.5539/gihs.v6n4p183

Ministério da Saúde, Secretaria de Vigilância em Saúde, Departamento de DST, Aids e Hepatites Virais. (2011). Pesquisa de conhecimento, atitudes e práticas na população brasileira. Brasília, Brasil: Autor.

Ministério da Saúde, Secretaria de Vigilância em Saúde, Departamento de DST, Aids e Hepatites Virais. (2013). Boletim Epidemiológico AIDS/DST. Brasília, Brasil: Autor.

Moghaddam, M. R., Mashhadi, I. E., Fathimoghadam, F., \& Pourafzali, S. J. (2015). Sexual and reproductive behaviors among undergraduate university students in Mashhad, a city in Northeast of Iran. Journal of Reproduction E Infertility, 16(1), 43-48. Retrieved from http://www.ncbi.nlm.nih.gov/ pmc/articles/PMC4322181/pdf/JRI-16-43.pdf

Oliveira, A. C., Oliveira, J. C., Pita, J. R., \& Cardoso, S. M. (2009). A aquisição do preservativo e o seu (não) uso pelos estudantes universitários. Revista de Enfermagem Referência, 2(11), 7-22. Retrieved from http://ui.esenfc.pt/rr/index.php?m odule $=$ rr\&target $=$ publicationDetails\&pesquisa $=\& i d$ $\operatorname{artigo}=2149$ \&id_revista $=4 \&$ id_edicao $=31$

Oliveira, L. F., Nascimento, E. G., Pessoa Junior, J. M., Cavalcanti, M. A., Miranda, F. A., \& Alchiere, J. C. (2015). Use of male condom in adolescents. Journal of Research Fundamental Care On-Line, 7(1), 1765-1773. doi: 10.9789/2175-5361.2015. v7i1.1765-1773

Rocha, Y. A., \& Silva, M. A. (2014). Conhecimento sobre HIV/ AIDS e práticas sexuais de estudantes de graduação em enfermagem. Estudos, 41(2), 275-289. Retrieved from http:// seer.ucg.br/index.php/estudos/article/view/3384

Sant' Anna, M. J., Carvalho, K. A., Passarelli, M. L., \& Coates, V. (2008). Comportamento sexual entre jovens universitários. Adolescência \& Saúde, 5(2), 52-56. Retrieved from http:// www.adolescenciaesaude.com/detalhe_artigo.asp?id =62 
Santos, S. M., \& Oliveira, M. L. (2009). Knowledge about aids and drugs among undergraduate students in a higher education institution in the state of Paraná. Revista Latino-Americana de Enfermagem, 17(4), 522-528. doi: 10.1590/S010411692009000400014

Silva, L. P., Camargo, F. C., \& Iwamoto, H. H. (2014). Comportamento sexual dos acadêmicos ingressantes me cursos da área da saúde de uma universidade pública. Revista de Enfermagem e Atenção a Saúde, 3(1), 39-52. Retrieved from: http://www.uftm.edu.br/revistaeletronica/index.php/ enfer/article/view/929
Sousa, M. C., Sousa, B. R., Lopes, I. M., \& Rodrigues, T. M. (2011). Conhecimentos e atitudes de estudantes de enfermagem frente à prevenção da AIDS. Revista Interdisciplinar UNINOVAFAPI, 5(3), 15-20. Retrieved from http://www. novafapi.com.br/sistemas/revistainterdisciplinar/v5n3/ pesquisa/p2_v5n3.pdf

Souza, M. M. (2007). Programa educativo sobre sexualidade e DST: Relato de experiência com grupo de adolescentes. Revista Brasileira de Enfermagem, 60(1), 102-105. doi: 10.1590/S0034-71672007000100020 
